\title{
Perbedaan model problem based learning dan discovery-inquiry ditinjau dari hasil belajar matematika siswa
}

\author{
The difference of problem based learning and discovery-inquiry for the \\ student mathematics learning result
}

\author{
Riski Nur Istiqomah Dinnullah ${ }^{1}$ \\ ${ }^{1}$ Jurusan Pendidikan Matematika, Universitas Kanjuruhan Malang. Jalan S. Supriyadi 48 Malang \\ E-mail: ky2_zahra@unikama.ac.id
}

\begin{abstract}
Abstrak
Tujuan dari penelitian ini adalah untuk mengetahui apakah terdapat perbedaan hasil belajar dengan menggunakan Model Problem Based Learning (PBL) dan Discovery-Inquiry pada siswa kelas VII di SMP Negeri 5 Malang tahun ajaran 2017/2018. Penelitian ini menggunakan dua kelas yang dipilih dengan menggunakan Teknik Purposive Sampling. Kedua kelas diberikan perlakuan yang bebeda dengan materi yang sama yakni Persamaan Linier Satu Variabel (PLSV). Untuk memperoleh data, peneliti menggunakan tes yang terlebih dahulu dilakukan uji coba instrumen meliputi uji validitas dan uji reliabilitas. Selanjutnya analisis data menggunakan uji normalitas, uji homogenitas, dan uji hipotesis (Independent Sampel T-Test). Hasil penelitian menunjukkan bahwa terdapat perbedaan hasil belajar menggunakan model pembelajaran Problem Based Learning (PBL) dan Discovery-Inquiry pada siswa kelas VII di SMP Negeri 5 Malang tahun ajaran 2017/2018 dengan diperoleh signifikansi $<0,05$ yaitu $0,013<0,05$. Selanjutnya, nilai rata-rata kelas yang menggunakan Model Problem Based Learning (PBL) lebih tinggi dari pada kelas dengan Model Discovery-Inquiry, yaitu dengan nilai rata-rata masing-masing kelas adalah 79,839 dan 71,613. Hal ini menunjukkan bahwa Model Problem Based Learning (PBL) lebih unggul daripada Model Discovery-Inquiry
\end{abstract}

Keyword: Problem Based Learning (PBL); Discovery-Inquiry; Hasil Belajar

\begin{abstract}
The aim of this research is to find out the difference in the learning result using the Problem Based Learning (PBL) model and the Discovery-Inquiry model on the 7th grade students of SMP Negeri 5 Malang year 2017/2018. This research used two classes chosen by Purposive Sampling technique. Both classes were given different treatments with the same material, that was One VariableLinear Equations. To obtain the data, the researcher used a test which had been tested through validity test and reliability test. After that, the data were analyzed with normality test, homogeneity test, and hypothesis test (Independent Sample T-Test). The result of this research indicated that there are some differences in the learning result using the Problem Based Learning (PBL) model and the Discovery-Inquiry model on the 7th grade students of SMP Negeri 5 Malang year 2017/2018. The significance obtained was $<0.05$, which was $0.013<0.05$. Next, the average grades of the class using the Problem Based Learning model was higher than the average grades of the class using the Discovery-Inquiry model. The average grades of each class were 79.839 and 71.613. This result indicates that the Problem Based Learning model is better than the Discovery-Inquiry model.
\end{abstract}

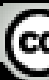

DOI: http://dx.doi.org/10.26486/jm.v3i1.654

$\mathrm{W}:$ http://ejurnal.mercubuana-yogya.ac.id/index.php/mercumatika

E:mercumatika@mercubuana-yogya.ac.id 


\section{PENDAHULUAN}

Pembelajaran matematika merupakan sebuah proses pemberian pengalaman belajar tentang matematika kepada siswa melalui kegiatan terencana yang disiapkan oleh guru (Winarso \& Dewi, 2017). Melalui pembelajaran matematika, guru sebagai fasilitator harus mampu membantu siswa dalam menemukan ide sendiri untuk menyelesaikan berbagai persoalan matematika yang dipelajarinya. Belajar matematika ini bertujuan untuk mendorong siswa agar mampu memecahkan berbagai permasalahan matematika berdasarkan proses yang rasional, logis serta pemikiran yang kritis. Penguasaan matematika perlu diberikan, mengingat matematika memiliki fungsi praktis dalam kehidupan sehari-hari dan memiliki kontribusi dalam perkembangan ilmu pengetahun lain (Perdana \& Slameto, 2016). Namun, fakta yang terjadi saat ini adalah siswa beranggapan bahwa belajar matematika adalah salah satu hal yang menakutkan dan siswa cenderung menghindarinya, bahkan mereka memandang matematika adalah salah satu mata pelajaran yang paling rumit (Ristanty, Dinnullah, \& Farida, 2017). Siswa sering mendapat kesulitan dalam menguasai persoalan yang terdapat dalam matematika. Tidak hanya itu saja, pembelajaran konvensional dan kurang interaktif menyebabkan banyak siswa kurang berminat dan pasif untuk belajar matematika.

Penyebab rendahnya hasil belajar siswa dipengaruhi oleh faktor internal dan eksternal (Misyanto, 2016). Pada faktor internal, siswa kurang berminat dalam mempelajari matematika karena paradigma yang terbentuk dalam pikiran siswa adalah matematika merupakan pelajaran yang sulit untuk dipelajari. Selain itu, kurangnya motivasi siswa juga memicu tidak adanya semangat siswa dalam belajar matematika. Hal ini dapat ditunjukkan dari sikap acuh tak acuh siswa, perhatian tidak tertuju pada pelajaran suka menggagu teman lainnya, bahkan siswa mudah putus asa pada saat guru meminta siswa untuk menyelesaikan soal. Sementara faktor eksternal yang mempengaruhi hasil belajar adalah metode mengajar guru yang membosankan dan tidak menarik bagi siswa.

Berdasarkan hasil observasi awal yang telah dilakukan di SMP Negeri 5 Malang kelas VII tahun ajaran 2018/2018 menunjukkan bahwa pembelajaran masih terpusat pada guru. Siswa hanya mendengarkan dan mencatat apa yang disampaikan dan tertulis di papan. Siswa juga kurang aktif dalam menanyakan apa yang belum dimengerti oleh siswa bahkan siswa lebih cenderung mengobrol dengan teman lainnya saat pembelajaran di kelas. Selain itu,hasil dari wawancara dengan guru mata pelajaran matematika siswa kelas VII diperoleh informasi bahwa hasil belajar siswa masih belum memuaskan. Hal ini terlihat dari hasil UAS yang ditunjukkan. Keadaan tersebut tentunya berimbas pada rendahnya hasil belajar matematika belajar siswa kelas VII. Berikut ini diberikan hasil UAS siswa kelas VII di SMP Negeri 5 Malang tahun ajaran 2017/2018.

Tabel 1. Hasil UAS Siswa Kelas VII Di SMP Negeri 5 Malang Tahun Ajaran 2017/2018

\begin{tabular}{llllll}
\hline \multirow{2}{*}{ Kelas } & \multirow{2}{*}{ Jumlah Siswa } & \multirow{2}{*}{ KKM } & \multicolumn{2}{c}{ Jumlah Siswa } & Persentase \\
\cline { 5 - 6 } & & & $\geq 75$ & $\leq 75$ & Ketuntasan \\
\hline VII-A & 30 & 75 & 24 & 6 & 80 \\
VII-B & 31 & 75 & 20 & 11 & 65 \\
VII-C & 31 & 75 & 21 & 10 & 68 \\
VII-D & 33 & 75 & 23 & 10 & 70 \\
VII-E & 32 & 75 & 23 & 9 & 72 \\
VII-F & 34 & 75 & 24 & 10 & 71 \\
VII-G & 35 & 75 & 23 & 12 & 66 \\
VII-H & 32 & 75 & 20 & 12 & 63 \\
VII-I & 32 & 75 & 21 & 12 & 66 \\
\hline
\end{tabular}

Pada tabel diatas terlihat bahwa masih terdapat siswa yang mendapatkan nilai dibawah KKM (Kriteria Ketuntasan Minimal). Hal ini menunjukkan bahwa hasil belajar matematika siswa perlu untuk ditingkatkan. Berdasarkan pengamatan di lapangan metode konvensional yang digunakan guru masih dirasa kurang efektif untuk melibatkan siswa aktif berperan dalam proses pembelajaran matematika. Saat siswa diberikan soal yang berbeda dari contoh sebelumnya siswa akan merasa 
kesulitan untuk mengerjakannya. Bahkan ketika diadakan diskusi untuk memecahkan soal matematis terlebih soal cerita, siswa masih belum dapat mengemukakan ide-ide matematis untuk menyelesaikan soal tersebut. Keadaan ini tentunya dikarenakan kurangnya penguasaan konsep yang diberikan.

Salah satu upaya guru untuk mengatasi permasalahan dalam pembelajaran matematika ini yakni dengan menerapkan model pembelajaran yang melibatkan siswa untuk aktif dalam pembelajaran matematika. Model pembelajaran memberikan suatu rancangan yang di dalamnya menggambarkan sebuah proses pembelajaran yang dapat dilaksanakan oleh guru dalam mentransfer pengetahuan maupun nilai-nilai kepada siswa. Model pembelajaran berperan penting terhadap kesuksesan kegiatan belajar mengajar. Jadi, guru dituntut untuk mampu memilih dan mengembangkan model pembelajaran matematika sesuai dengan tujuan pembelajaran yang ingin dicapai, serta mampu meningkatkan hasil belajar siswa. Model pembelajaran yang dapat mengarahkan siswa untuk aktif dalam memperoleh pengetahuan sendiri diantaranya model pembelajaran Problem Based Learning (PBL) dan model pembelajaran Discovery-Inquiry.

Pada pembelajaran Problem Based Learning (PBL), siswa dituntut untuk lebih aktif dalam menemukan masalah dan memecahkan masalah tersebut melalui ide-ide yang digali dan dikumpulkan dan kemudian digunakan untuk menyimpulkan permasalahan yang dihadapi (Pranoto, Harlita, \& Santosa, 2017). PBL memberikan metode belajar yang menggunakan masalah sebagai langkah awal dalam mengumpulkan dan mengintegrasikan pengetahuan baru (Firmansyah, Kosim, \& Ayub, 2015). Metode ini juga berfokus pada keaktifan siswa dalam kegiatan pembelajaran. Siswa tidak lagi diberikan materi belajar secara satu arah seperti pada metode pembelajaran konvensional namun lebih pada pembelajaran yang berpusat pada siswa (Fauzan, Gani, \& Syukri, 2017; Nelfiyanti \& Sunardi, 2017). Problem Based Learning dapat meningkatkan peran siswa dalam belajar serta meningkatkan prestasi siswa karena dalam proses pembelajarannya, siswa memahami secara mandiri cara menggunakan konsep dan proses interaksi untuk menilai hal yang diketahui, mengidentifikasi, mengumpulkan informasi dan secara kolaborasi mengevaluasi hipotesis berdasarkan data yang telah diperolehnya (Suci, 2008). Melaui Problem Based Learning, siswa merefleksikan pengalamannya, sehingga siswa dapat mengembangkan kemampuan berpikir (penalaran, komunikasi dan koneksi) dalam memecahkan masalah yang bermakna, relevan dan kontekstual (Saleh, 2013). Melalui hasil penelitian (Yanti \& Prahmana, 2017) diketahui bahwa Problem Based Learning memberikan nilai kemampuan berpikir kritis matematika siswa yang lebih tinggi jika dibandingkan dengan Model Guided Inquiry. Selain itu, hasil penelitian (Bungel, 2014) menunjukkan bahwa Pembelajaran Problem Based Learning dapat meningkatkan hasil belajar matematika siswa kelas VIII di SMP Negeri 4 Palu.

Model pembelajaran Discovery-Inquiry merupakan metode pembelajaran yang menggabungkan model pembelajaran discovery dan inquiry. Belajar metode inkuiri discovery merupakan suatu kegiatan belajar yang mengutamakan aktifitas peserta didik. Inkuiri menekankan pada proses mencari atau penelitiannya, sedangkan discovery menekankan pada penemuannya. Jika seseorang menggunakan metode pencarian (berinkuiri), kemungkinan besar akan menemukan, dan suatu penemuan (discovery) adalah hasil dari suatu pencarian (Magasida, 2017). Pada model pembelajaran Discovery-Inquiry, siswa mendapatkan pengetahuannya melalui observasi, eksperimen dan pemecahan masalah. Pengetahuan yang diperoleh siswa akan lebih bermakna karena dalam model pembelajaran ini, siswa secara mandiri yang mencari dan menemukan pengetahuannya (Masitoh, 2016; Nugraha, Kirana, \& Saepuzaman, 2014). Konsep pada pembelajaran ini mangacu pada kegiatan belajar yang tidak lagi konvensional tetapi guru lebih sebagai fasilitator yang lebih memperhatikan proses dan hasil serta membimbing siswa untuk membawa pengetahuannya sendiri-sendiri, dan mampu mengkonstruksi pembelajaran sesuai tahap perkembanganya (Palupi, Kamsiyati, \& Budiarto, 2013; Wartini, Al-Asy'ar, \& Multahada, 2017). Pembelajaran dengan menggunakan Discovery-Inquiry, tidak hanya membimbing siswa untuk menyelidiki secara mendalam tentang konsep tetapi juga membiasakan siswa dalam menyelesaikan masalah yang diberikan (Tompo, Ahmad, \& Muris, 2016). Sementara, hasil penelitian (Sari, 2014) menunjukkan bahwa terdapat pengaruh penerapan metode pembelajaran Discovery-Inquiry terhadap kemampuan pemecahan masalah matematika dengan materi Bangun Datar Segitiga siswa kelas VII di SMP Islam YLPI Pekanbaru. Hal tersebut juga diketahui dari nilai rata-rata kelas eksperimen yang lebih tinggi dibandingkan dengan nilai rata-rata pada kelas kontrol. Selain itu, 
hasil penelitian (Rahmadani, 2012) menunjukkan bahwa mampu menungkatakan motivasi dan hasil belajar siswa SMP Negeri 2 Juwangi Boyolali.

Penggunaan model pembelajaran yang tepat akan mendukung proses belajar siswa, meningkatkan keaktifan dan interaksi antara siswa dan guru maupun antar siswa tersebut. Pemilihan metode pembelajaran yang sesuai sangat berpengaruh dalam menciptakan suasana kelas agar lebih bermakna (meaningful learning) sehingga menumbuhkan minat dan siswa lebih aktif di kelas. Hal ini tentunya akan memberikan pengaruh pada hasil belajar yang lebih maksimal.

\section{METODE}

Penelitian ini merupakan penelitian dengan pendekatan kuantitatif. Sementara, Jenis penelitian yang digunakan adalah eksperimen semu (quasi experiment). Penelitian dilaksanakan di SMP Negeri 5 Malang tahun ajaran 2017/2018. Populasi dalam penelitian ini adalah seluruh siswa kelas VII di SMP Negeri 5 Malang berjumlah 290 siswa yang dikelompokkan secara pararel dengan jumlah 9 kelas. Sampel yang digunakan diambil dari populasi dengan teknik purposive sampling. Pemilihan sampel dengan teknik ini dilakukan dengan mempertimbangkan beberapa hal sebagai berikut: (1) berdasarkan hasil UAS, nilai dari kelas tersebut tidak berbeda jauh dari kelaskelas yang lainnya sehingga telah mewakili populasi dan (2) pertimbangan guru mata pelajaran matematika kelas VII pada pemilihan dengan melihat keadaan siswa pada kedua kelas tersebut yang kurang semangat dalam belajar matematika. Dengan demikian, kelas VII-B dipilih sebagai kelas eksperimen 1 yang diberikan perlakuan model Problem Based Learning (PBL) dan VII-C sebagai kelas eksperimen 2 yang diberikan perlakuan model Discovery-Inquiry.

Terdapat dua variabel dalam penelitian ini yakni variabel bebas dan variabel terikat. Variabel bebas dalam penelitian ini adalah model Problem Based Learning (PBL) dan model DiscoveryInquiry. Sementara, variabel terikatnya adalah hasil belajar. Instrumen yang digunakan dalam penelitian ini adalah tes dan dokumentasi. Tes dalam penelitian ini dilakukan dalam 2 tahap yakni pada awal pembelajaran (pretest) yang diberikan untuk mengetahui hasil belajar siswa sebelum perlakuan dan pada akhir pembelajaran (posttest) yang diberikan untuk mengetahui hasil belajar siswa setelah perlakuan. Sebelum diberikan pada sampel terlebih dahulu dilakukan uji validitas dan uji reliabilitas. Validasi instrumen hasil belajar matematika dilakukan oleh 2 validator yang terdiri dari ahli pembelajaran dan ahli materi. Soal tes yang sudah divalidasi oleh validator kemudian diujicobakan kepada siswa di luar kelas penelitian. Untuk menghitung validitas butir soal menggunakan rumus korelasi product moment dan uji reliabilitas menggunakan Alpha Cronbach.

Teknik analisis yang dilakukan yakni uji hipotesis menggunakan uji Independent Sample TTest. Sebelum uji analisis dilakukan, sampel harus dilakukan uji prasyarat yaitu uji normalitas dan uji homogenitas. Uji normalitas menggnakan uji Kolmogorov-Smirnov dan uji homogenitas menggunakan uji Levene's test dengan signifikansi 0.05 .

Instrumen yang digunakan dalam penelitian ini adalah tes antara lain sebagai berikut:

a. Pretest

Untuk mengumpulkan data yang diperlukan dalam penelitian ini digunakan teknik Pretest. Pretest diberikan untuk mengetahui hasil belajar yang dimiliki siswa sebelum diberikan perlakuan. Bentuk soal pretest yakni uraian yang berjumlah 4 butir soal.

b. Posttest

Posttest diberikan untuk mengetahui hasil belajar yang dimiliki siswa setelah diberikan perlakuan. Hasil tes yang diberikan kelas eksperimen 1 setelah menggunakan Problem Based Learning (PBL) dan kelas eksperimen 2 setelah menggunakan model Discovery-Inquiry yang akan dianalisis. Bentuk soal posttest yakni uraian yang berjumlah 4 butir soal.

\section{Uji Hipotesis}

Uji hipotesis pada penelitian ini digunakan untuk mengetahui perbedaan hasil belajar menggunakan model pembelajaran Problem Based Learning (PBL) dan Discovery-Inquiry pada 
siswa kelas VII di SMP Negeri 5 Malang Tahun Ajaran 2017/2018. Dalam menguji hipotesis penelitian menggunakan IBM SPSS Statistics 22 dan teknik analisis yang digunakan Uji Independen Sampel T-Test. Hipotesis yang akan diuji pada hasil belajar siswa adalah sebagai berikut:

Ha: Ada perbedaan hasil belajar menggunakan model pembelajaran Problem Based Learning (PBL) dan Discovery-Inquiry pada siswa kelas VII di SMP Negeri 5 Malang Tahun Ajaran 2017/2018.

Ho: Tidak ada perbedaan hasil belajar menggunakan model pembelajaran Problem Based Learning (PBL) dan Discovery-Inquiry pada siswa kelas VII di SMP Negeri 5 Malang Tahun Ajaran 2017/2018.

Sementara, kriteria pengujian hipotesis yaitu :

Jika signifikansi $<0.05$, maka Ha tidak ditolak.

Jika signifikansi $>0.05$, maka Ha ditolak.

\section{HASIL DAN PEMBAHASAN}

Uji normalitas pada penelitian ini menggunakan uji Kolmogorov-Smirnov dengan taraf signifikansi 0,05 . Hasil uji normalitas dapat dilihat pada tabel berikut ini. Berdasarkan tabel 1 terlihat bahwa Nilai pretest kelas eksperimen 1 mempunyai signifikansi 0,109 dan kelas eksperimen 2 mempunyai signifikansi 0,183. Dari kedua hasil perhitungan tersebut terlihat bahwa nilai signifikansi $>0,05$. Sedangkan pada posttest untuk kelas eksperimen 1 mempunyai signifikansi 0,200 dan kelas eksperimen 2 mempunyai sig-nifikansi 0,096. Dari kedua hasil perhitungan tersebut terlihat bahwa nilai signifikansi $>0,05$ untuk masing-masing kelas maka didapatkan bahwa Ho tidak ditolak yang berarti sampel berasal dari populasi yang berdistribusi normal. Dengan demikian, dapat diketahui bahwa data berdistribusi normal.

Selanjutnya dilakukan uji homogenitas menggunakan Levene's test pada nilai pretest, diperoleh bahwa nilai signifikansi 0,397, dimana 0,397>0,05. Sehingga dapat disimpulkan bahwa Ho tidak ditolak data sampel berasal dari populasi yang memiliki variansi yang homogen karena nilai signifikansi $>0,05$.

Setelah melakukan pengujian normalitas dan homogenitas, dapat disimpulkan bahwa kedua sampel yaitu kelas VII-B sebagai kelas eksperimen 1 dan kelas VII-C sebagai kelas eksperimen 2 berdistribusi normal dan homogen. Uji hipotesis dilakukan untuk mengetahui ada tidaknya perbedaan model pem-belajaran Problem Based Learning (PBL) dan model pembelajaran Discovery-Inquiry terhadap hasil belajar siswa menggunakan uji Independen Sampel T-Test dengan bantuan IBM SPSS Statistics 22. Hasil uji hipotesis pretest menunjukkan bahwa tidak terdapat per-bedaan hasil belajar pada kedua kelas.

Tabel 2. Hasil Uji Hipotesis Pretest

\begin{tabular}{llll}
\hline Sumber & Sig. & Hasil & Keputusan \\
\hline $\begin{array}{l}\text { Nilai hasil } \\
\text { belajar }\end{array}$ & 0,856 & $0,856>0,05$ & Ha ditolak \\
\hline
\end{tabular}

Pada tabel 2 diperoleh bahwa nilai signifikansi $>0,05$, yaitu $0,856>0,05$ sehingga dapat dinyatakan bahwa Ho tidak ditolak dan Ha ditolak. Hal ini dapat diartikan bahwa tidak ada perbedaan hasil belajar menggunakan model pembelajaran Problem Based Learning (PBL) dan Discovery-Inquiry pada siswa kelas VII di SMP Negeri 5 Malang tahun ajaran 2017/2018. Sementara hasil uji hipotesis pada posttest diberikan pada tabel berikut ini.

Tabel 3. Hasil Uji Hipotesis Posttest

\begin{tabular}{llll}
\hline Sumber & Sig. & Hasil & Keputusan \\
\hline $\begin{array}{l}\text { Nilai hasil } \\
\text { belajar }\end{array}$ & 0,013 & $0,013<0,05$ & $\begin{array}{l}\text { Ha tidak } \\
\text { ditolak }\end{array}$ \\
\hline
\end{tabular}

Pada tabel 3 didapatkan bahwa nilai signifikansi $<0,05$, yaitu $0,013<0,05$ sehingga dapat dinyatakan bahwa Ho ditolak dan Ha tidak ditolak. Hal ini dapat diartikan bahwa terdapat 
perbedaan hasil belajar menggunakan model pembelajaran Problem Based Learning (PBL) dan Discovery-Inquiry pada siswa kelas VII di SMP Negeri 5 Malang tahun ajaran 2017/2018. Berdasarkan uji hipotesis yang dilakukan pada pretest dan posttest diperoleh bahwa sebelum diberikan perlakuan kedua kelas tidak terdapat perbedaan hasil belajar dan setelah diberikan perlakuan terdapat perbedaan hasil belajar pada kedua kelas tersebut.

Selain itu, sebelum diberikan perlakuan rata-rata pada kedua kelas tidak terdapat perbedaan yang signifikan. Hasil belajar pretest kelas eksperimen 1 yaitu 58,935, sedangkan kelas eksperimen 2 yaitu 59,484. Setelah diberikan per-lakuan, kedua kelas diberi posttest untuk melihat hasil belajar siswa. Berdasarkan hasil posttest diperoleh rata-rata hasil belajar kelas eksperimen 1 yaitu 79,839, sedangkan kelas eksperimen 2 yaitu 71,613. Adapun grafik histogram rata-rata nilai hasil belajar siswa kelas yang menggunakan model pembelajaran Problem Based Learning (PBL) dan Discovery-Inquiry adalah sebagai berikut.

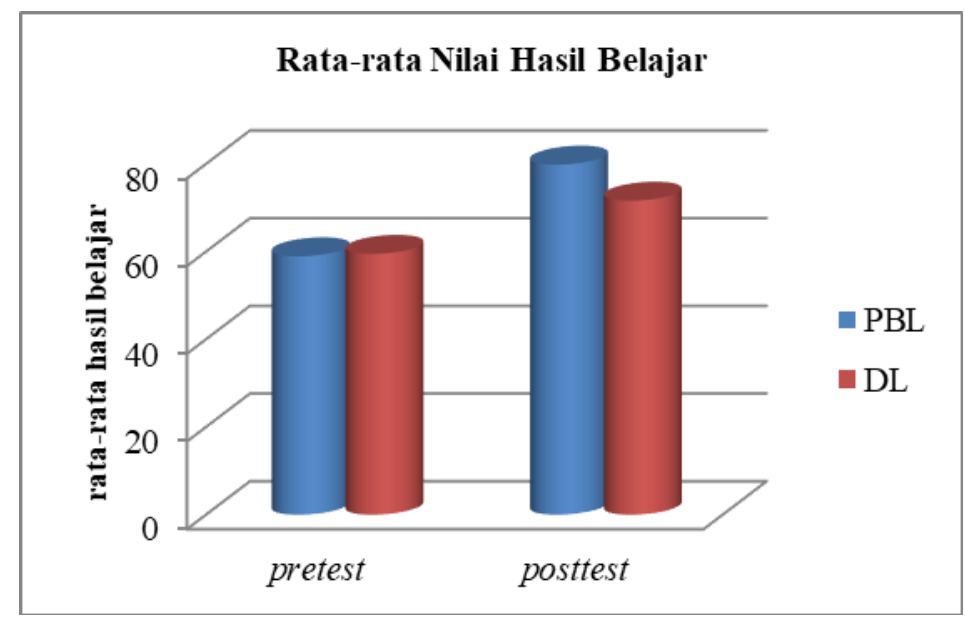

Gambar 1. Grafik rata-rata nilai hasil belajar

Pada gambar 1. memperlihatkan bahwa kedua kelas memiliki rata-rata nilai yang berbeda tetapi tidak signifikan sebelum diberikan perlakuan. Sebelum diberikan perlakuan, rata-rata kelas eksperimen 2 lebih tinggi yaitu 0,549 dari pada kelas eksperimen 1. Namun setelah diberikan perlakuan terdapat perbedaan secara signifikan pada kelas eksperimen 1 dan kelas eksperimen 2. Setelah diberikan perlakuan, rata-rata kelas eksperimen 1 lebih tinggi yaitu 8,226 dari pada kelas eksperimen 2. Dilihat dari hasil belajar siswa tersebut, nilai yang diperoleh siswa pada pembelajaran dengan Problem Based Learning lebih baik daripada menggunakan model DiscoveryInquiry.

Perbedaan keefektivan kedua proses pembelajaran ini terlihat dari hasil belajar matematika siswa dan proses pembelajaran pada kelas eksperimen 1 yang lebih baik jika dibandingkan dengan kelas eksperimen 2. Hal ini dikarenakan pada pembelajaran Problem Based Learning, guru memberikan kebebasan kepada siswa untuk berfikir dan mencari ide gagasan dari berbagai sumber serta melakukan uji coba penyelesaian dari ide yang telah diperolehnya. Guru yang berperan sebagai fasilitator juga memberikan bimbingan kepada siswa dengan memberikan beberapa pertanyaaan yang mengarahkan siswa untuk menemukan informasi yang dibutuhkan. Metode ini jelas terlihat efektif mampu membuat siswa lebih termotivasi, aktif, bersemangat, dan percaya diri ketika menjelaskan hasil diskusi penyelesaian soal di depan kelas. Keaktifan motorik siswa lebih terlihat pada penerapan Problem Based Learning karena pada kelas dengan penerapan PBL siswa lebih bebas dalam melakukan percobaan tapi masih terkontrol dalam pengawasan guru dan siswa secara kerjasama dalam melakukan percobaan sehingga setiap siswa aktif dalam melakukan percobaan (Pranoto et al., 2017).

Ide-ide matematis yang ditemukan oleh siswa secara mandiri membuat siswa lebih mudah dalam menyelesaikan soal-soal yang diberikan. Ketika diberikan soal lain, siswa mampu untuk menyelesaikan dengan baik dan benar. Kegiatan dalam Problem Based Learning yang melibatkan siswa secara langsung dalam menemukan konsep penyelesaian masalah secara mandiri akan 
membuat siswa dapat menemukan pengetahuan dengan lebih mudah dan bertahan lama dalam ingatannya (Putri \& Agustyaningrum, 2017). Keadaan tersebut menunjukkan bahwa Problem Based Learning mampu meningkatkan pengetahuan serta mengembangkan keterampilan berpikir siswa. Pemecahan masalah yang dilakukan secara mandiri ini tentunya dapat memberikan suatu pengalaman konkret yang dapat digunakan untuk memecahkan masalah-masalah serupa, karena pengalaman tersebut akan memberikan makna tersendiri bagi siswa.

\section{SIMPULAN}

Berdasarkan hasil dan pembahasan penelitian yang dipaparkan sebelumnya, kesimpulan yang dapat diambil adalah hasil uji hipotesis data hasil posttest menunjukkan bahwa terdapat perbedaan antara siswa yang belajar dengan model pembelajaran Problem Based Learning (PBL) dengan Discovery-Inquiry terhadap hasil belajar siswa kelas VII di SMP Negeri 5 Malang. Hal ini dapat dilihat dari nilai rata-rata hasil belajar matematika siswa kelas VII SMP Negeri 5 Malang yang diberikan Model pembelajaran Problem Based Learning (PBL) lebih baik dibandingkan dengan model pembelajaran Discovery-Inquiry.

\section{DAFTAR PUSTAKA}

Bungel, M. F. (2014). Penerapan Model Pembelajaran Problem Based Learning Untuk Meningkatkan Hasil Belajar Siswa Kelas Viii Smp Negeri 4 Palu Pada Materi Prisma. Jurnal Elektronik Pendidikan Matematika Tadulako, 2(1), 45-54.

Fauzan, M., Gani, A., \& Syukri, M. (2017). Penerapan Model Problem Based Learning Pada Pembelajaran Materi Sistem Tata Surya Untuk Meningkatkan Hasil Belajar Siswa. Jurnal Pendidikan Sains Indonesia, 5(1), 27-35. https://doi.org/10.15713/ins.mmj.3

Firmansyah, A., Kosim, \& Ayub, S. (2015). Pengaruh Model Pembelajaran Berbasis Masalah Dengan Metode Eksperimen Pada Materi Cahaya Terhadap Hasil Belajar Fisika Siswa Kelas Viii Smpn 2 Gunungsari Tahun Ajaran 2014/2015. Jurnal Pendidikan Fisika Dan Teknologi, $1(3), 154-159$.

Magasida, D. (2017). Penerapan Metode Discovery Inkuiri Pada Pembelajaran Sains Anak Usia Dini. AWLADY: Jurnal Pendidikan Anak, 3(1), 1-12.

Masitoh, S. (2016). Peningkatan Hasil Belajar IPS Melalui Strategi Inquiry Discovery Learning Di Kelas IV Sdn Kecamatan Cikarang Utara Kabupaten Bekasi. Jurnal Pendidikan Dasar, 7(2), 341-360.

Misyanto. (2016). Analisis Faktor Penyebab Rendahnya Hasil Belajar Peserta Didik Kelas V Pada Mata Pelajaran Matematika. Anterior Jurnal, 15(2), 144-150.

Nelfiyanti, \& Sunardi, D. (2017). Penerapan Metode Problem Based Learning Dalam Pelajaran Al -Islam II Di Fakultas Teknik Universitas Muhammadiyah Jakarta. Spektrum Industri, 15(1), 111-119. https://doi.org/10.3109/02699052.2014.919530

Nugraha, M. G., Kirana, K. H., \& Saepuzaman, D. (2014). PF-07: EFEKTIFITAS MODEL PEMBELAJARAN DISCOVERY-INQUIRY UNTUK MENINGKATKAN KETERAMPILAN BERPIKIR RASIONAL SISWA. In Prosiding Seminar Nasional Fisika (E-Journal) SNF2014 (pp. 43-47). Jakarta: Jurusan Fisika FMIPA Universitas Negeri Jakarta.

Palupi, L. L., Kamsiyati, S., \& Budiarto, T. (2013). Pengaruh Metode Inquiry Discovery Terhadap Hasil Belajar Matematika. Jurnal Pendidikan PGSD, 1(6), 1-6.

Perdana, S. A., \& Slameto. (2016). Penggunaan Metode Problem Based Learning (PBL) Berbantuan Media Audio Visual Untuk Meningkatkan Hasil Belajar Matematika Siswa Sekolah Dasar. Jurnal Pendidikan Dasar, 4(2), 73-78.

Pranoto, Harlita, \& Santosa, S. (2017). Perbandingan Model Pembelajaran Problem Based Learning dan Guided Discovery Learning terhadap Keaktifan Siswa Kelas X SMA. 
Bioedukasi, 10(1), 18-22. https://doi.org/DOI: http://dx.doi.org/10.20961/bioedukasiuns.v10i1.8604

Putri, I. S., \& Agustyaningrum, N. (2017). Efektifitas Model Pembelajaran Discovery-Inquiry untuk Meningkatkan Keterampilan Berpikir Rasional Siswa. Jurnal Mercumatika, 1(2), 97103.

Rahmadani. (2012). Peningkatan Motivasi Dan Prestasi Belajar Matematika Melalui Pembelajaran Discovery Inquiry Type Pictorial Riddle. Naskah Publikasi. Universitas Muhammadiyah Surakart. Retrieved http://www.dt.co.kr/contents.html?article_no $=2012071302010531749001$

from

Ristanty, E., Dinnullah, R. N., \& Farida, N. (2017). Penerapan Model Pembelajaran Inkuiri Terbimbing Pada Materi Segiempat dan Segitiga Terhadap Pemahaman Konsep Matematika Di Smp Islam Soerjo Alam. Pi:Mathematics Education Journal, 1(1), 8-14.

Saleh, M. (2013). Strategi Pembelajaran Fiqh dengan Problem-Based Learning. Jurnal Ilmiah DIDAKTIKA, XIV(1), 190-220.

Sari, D. P. (2014). Pengaruh Penerapan Metode Pembelajaran Discovery-Inquiry Terhadap Kemampuan Pemecahan Masalah Matematika Siswa SMP Islam YLPI Pekanbaru. Skripsi. Universitas Islam Negeri Sultan Syarif Kasim Riau.

Suci, N. (2008). Penerapan Model Problem Based Learning Untuk Meningkatkan Partisipasi Belajar Hasil Belajar Teori Akuntansi Mahasiswa Jurusan Ekonomi Undiksha. Jurnal Penelitian dan Pengembangan Pendidikan Udiksha, 2(1), 74-86.

Tompo, B., Ahmad, A., \& Muris, M. (2016). The development of discovery-inquiry learning model to reduce the science misconceptions of junior high school students. International Journal of Environmental and Science Education, 11(12), 5676-5686. https://doi.org/10.4102/koers.v79i2.2143

Wartini, A., Al-Asy'ar, M. K. H., \& Multahada, A. (2017). Menggagas Model Pembelajaran Discovery-Inquiry pada Pendidikan Anak Usia Dini. Intizar, 23(1), 151-164.

Winarso, W., \& Dewi, W. Y. (2017). Berpikir kritis siswa ditinjau dari gaya kognitif visualizer dan verbalizer dalam menyelesaikan masalah geometri. BETA Jurnal Tadris Matematika, 10(2), 117-133.

Yanti, O. F., \& Prahmana, R. C. I. (2017). Model Problem Based Learning, Guided Inquiry, Dan Kemampuan Berpikir Kritis Matematis. Jurnal Review Pembelajaran Matematika, 2(2), 120-130. 